Отримано: 13 березня 2018 р.

Прорецензовано: 15 березня 2018 р.

Прийнято до друку: 19 березня 2018 р.

e-mail: oksanakharlay@gmail.com

DOI: $10.25264 / 2519-2558-2018-1(69) / 2-210-213$
Oksana Kharlay. Representation of female positive inner attributes in polish and chinese proverbs from an ethnolinguistic perspective. Наукові записки Начіонального університету «Острозька академія»: серія «Філологія». Острог : Вид-во НаУОА, 2018. Вип. 1(69), ч. 2, березень. С. 210-213.

Oksana Kharlay,

Macau University of Science and Technology, Macau, China

\title{
REPRESENTATION OF FEMALE POSITIVE INNER ATTRIBUTES IN POLISH AND CHINESE PROVERBS FROM AN ETHNOLINGUISTIC PERSPECTIVE
}

The article investigates and compares the positive inner attributes of women reflected in Chinese and Polish proverbs. The sources of the features that underlie the representations of female positive inner attributes from proverbs were found to draw mostly from traditional (national) culture, cultural symbolism, and social and gender stereotypes. Social beliefs, ethnic and gender prejudice towards women in both societies, as well as ethno-cultural information accumulated in the proverbs, were revealed by means of the ethnolinguistic approach to their critical analysis. In both cultures, inner attributes provide a clear moral compass pointing to an ideal female behaviour. However, we only found evidence in Chinese proverbs of low intellectual and cultural qualities representing positive attributes of a good spouse.

Key words: Chinese and Polish proverbs, female positive inner attributes, ethnolinguistics, comparison, linguistic worldview.

\section{Харлай Оксана,}

Університет Науки та Технологї Макао, Макао, Китай

\section{ВІДОБРАЖЕННЯ ЖІНОЧИХ ПОЗИТИВНИХ ВНУТРІШНІХ ЯКОСТЕЙ В КИТАЙСЬКИХ ТА ПОЛЬСЬКИХ ПРИСЛІВ’ЯХ: ЕТНОЛІНГВІСТИЧНИЙ ПІДХІД}

У статті досліджуються та порівнюються позитивні внутрішні якості жінок, відображені в китайських та польських прислів'ях. Було встановлено, шо традичійна (начіональна) культура, культурна символіка, сочіальні та гендерні стереотипи є джерелами особливостей, які лежать в основі аналізованих жіночих позитивних внутрішніх якостей. Критичний аналіз прислів ’̈в вияв сочіальні вірування, етнічне та гендерне упередження щуодо жінок в обох суспільствах. Так в обох культурах внутрішні якості забезпечують чіткий моральний компас, що вказує на ідеальну жіночу поведінку. Однак лише в китайських прислів'ях ми знайшли докази, щзо низький інтелектуальний та культурний рівень є позитивним атрибутом хорошої дружини.

Ключові слова: китайські та польські прислів'я, жіночі позитивні внутрішні якості, етнолінгвістика, порівняння, мовна та концептуальна картина світу.

\section{Харлай Оксана,}

Университет Науки и Техники Макао, Макао, Китай

\section{ОТОБРАЖЕНИЕ ЖЕНСКИХ ПОЗИТИВНЫХ ВНУТРЕННИХ КАЧЕСТВ В КИТАЙСКИХ И ПОЛЬСКИХ ПОСЛОВИЦАХ: ЭТНОЛИНГВИСТИЧЕСКИЙ ПОДХОД}

В статье исследуются и сравниваются положительные внутренние качества женшин, отраженные в китайских и польских пословицах. Было установлено, что традиционная (национальная) культура, культурная символика, социальные и гендерные стереотипь являются источниками особенностей, которые лежат в основе анализируемых женских положительных внутренних качеств. Критический анализ пословии установил проявления сочиальных верований, этнических и гендерных предубеждений в отношении женщин в обоих обществах. Так в обоих культурах внутренние качества обеспечивают четкий моральньй компас, указывающий на идеальное женское поведение. Однако только в китайских пословицах мы нашли доказательства, что низкий интеллектуальный и культурный уровень является положительным атрибутом хорошей жень.

Ключевые слова: китайские и польские пословицы, женские положительные внутренние качества, этнолингвистика, сравнение, языковая и концептуальная картина мира.

Introduction. This work analyses the positive female inner attributes expressed in Chinese and Polish proverbs and what images and symbols are deployed to express them. This approach aims at contributing to the reconstruction of two distant linguistic worldviews - Polish and Chinese through the prism of ethnolinguistics.

Theoretical background. The way language, society and culture interact was the focus of interest with many XIX-XX century linguists and thinkers (W. Humboldt, F. Boas, E. Sapir and B. Whorf, L. Vygotsky). Despite differences in scholars' views and formulated theories, they all agreed that language is more than just a means of communication. It does not merely 'copy' the reality, but shapes people's perception of it. Language is inextricable from the culture of any society and it always contains some form of explicit or implicit reference to it. As Saussure observed "the culture of a nation exerts an influence on its language, and the language, on the other hand, is largely responsible for the nation" [Scar., p. 20]. Thus, language, culture and society represent the three key pillars of ethnolinguistics.

In order to avoid any ambiguity in terminology usage, in this work we will employ the ethnolinguistic approach of the linguistic analysis already put forward and applied by Jerzy Bartmiński. From the scholar's perspective, in the research on language-culture relationship the focus must remain clearly on finding 'manifestations of culture in language' [3, p. 10].

Linguistic worldview (hereafter LWV) is the central concept in ethnolinguistics. It has been extensively studied by renowned scholars such as J. Anusiewicz, J. Bartmiński, R. Grzegorczykowa, N. Tolstoy, S. Tolstaya, J. Underhill. Despite differences in the definitions and interpretations, they all investigated LWV realisations within the language-culture-thought triangle. In this paper we accepted the definition of LWV proposed by J. Bartmiński [4, p. 23] who stated that it is "a language-entrenched interpretation of reality, which can be expressed in the form of judgments about the world, people, things or events." He pictures LVWs as a multi- 
component entity and its reconstruction requires the analysis of a broad material data including both syntagmatic and paradigmatic network of lexico-semantical relations (synonyms and antonyms, hyponyms and hypernyms, derivatives, collocations, etc.). Furthermore, the scholar puts additional emphasis on the prime analyses of proverbs as original and not borrowed minimal clichéd texts.

Proverbs are generally known as part of the cultural knowledge and are employed as shortcuts to express 'pearls of wisdom' or just a relevant commentary drawn from an elusive 'common knowledge', often expressed through a rhymed and humorous play on words. A proverb follows Darwinian laws and survives in the spoken and written form within a linguistic unit on the strength of its cultural and temporal relevance, sometimes wrapped in a timeless comedic envelope.

In the literature, proverbs are taken as "culturally confirmed frozen texts of a prototypical practice used as an illocution over a categorical action in a setting for a projected view of life" [5]. They function as a means of transfer of indigenous knowledge and wisdom from generation to generation and "connect the human and the world and they are the way language gives the opportunity to the human to impact the world" [1, p. 12].

More importantly, proverbs supervise people's daily actions and evaluate them either positively or negatively. They comprise social and cultural collective beliefs about the norms of gender qualities, attributes, roles, behaviour and their deviations. Besides, they vividly express the implications of gender stereotypes encrypted in languages and intended to directly influence interlocutors. In other words, proverbs involve "coordinating language with ways of acting, interacting, valuing, believing, feeling, and with bodies, clothes, non-linguistic symbols, objects, tools, etc." [6, p. 25].

Literature Review. Proverbs have been analysed by many linguists and scholars spanning a range of topics and research foci. For instance, Mieder looked into the nature of proverbs; Goodwin and Wenzel, Honeck and Kibler, Kemper, and Pasamanick studied proverbs in relation to the cognitive aspect; Lieber, and Yankah focused on the pragmatics of proverbs; Paltridge and Tyler analysed the historical and cultural contexts within which proverbs are structured.

The representation of females in proverbs has been investigated both within individual languages, for instance, in Igbo and Kurdish, and cross-culturally, in order to highlight differences in perception; for instance, Rasul compared the portrayal of women in English and Urdu proverbs from a socio-linguistic and critical discourse analysis perspective. Nabifar instead investigated the differences between English and Persian proverbs in relation to human cognitive system. Despite being unrelated, the scholar found common elements in both languages, suggesting similar mental mechanisms resting on a shared deeper structure. Chinese proverbs stereotypically depicting men and women were researched by Lee who discovered gender discrimination and male-'firstness' represented in them. However, the scholar also reported biased subjective approach of some linguists who mainly "focused on the portrayal of women rather than men" [7, p. 562] in Chinese proverbs analysis.

Research rationale. There were no observed researches on comparison of female inner positive attributes represented in Chinese and Polish proverbs. The comparison of proverbs will allow identifying both universal and national-specific characteristics of the two distant LWVs - Chinese and Polish and contribute to their reconstruction.

Objective of the Study. Based on the premise that proverbs describe and regulate roles of women in the community during their socialisation process, this paper focuses on the female positive inner attributes reflected in Chinese and Polish proverbs and their implications on women's behaviour within the social settings.

Description of Findings. Virtue - General. This group embraces proverbs that describe Chinese and Polish society's attitude to female and her general virtuosity. According to Confucian beliefs, the dominating philosophy in old and contemporary China, it is essential for a girl to be virtuous and enjoy a good reputation: failing would lead to 'shame' and social disgrace. Chinese proverbially praise virtuous women stating they are a serious moral support to husbands: 女德無極; 婦怨無終 (nü té wú chí; fù yǜan wú chùng) 'A maid's virtue is unlimited; a wife's resentment without end' [ShaoLan, p. 378]; 忠臣不事二君; 貞婦不事二夫 (chūng chén pù shì èrh chë̈n; chēn fù pù shì èrh fü) 'A loyal minister will serve but one Prince; a virtuous woman but one husband' [ShaoLan, p. 378]; 家有賢妻。男人不遭橫事 (chīa yŭ hsiēn chī, nán jén pù tsāo hùn shìh) 'A virtuous wife saves her husband from evil ways' [ShaoLan, p. 377]; 娶媳求淑女。勿討厚㚗 (chü hsì chiú shú nü, wù chì hòu lién) 'In marrying a son seek a virtuous maiden, and scheme not for a rich dowry' [ShaoLan, p. 370]; 賢婦令夫貴。惡婦令夫賤 (hsién fü ling fü kuèi, ò fù ling fü chièn) 'A virtuous wife causes her husband to be honoured; a bad one brings him to shame' [ShaoLan, p. 377]; 癡漢怕老婆。賢女敬丈夫 (chih hàn pà lăo pó; hsien nü chìng chàng fü) 'The fool fears his old woman; but the virtuous wife reverences her husband' [ShaoLan, p. 374]; 娶妻不在美貌, 賢德便好 (chü chī pù tsài yén sè, hsién té pìen hăo) 'the excellence of a wife consists not in her beauty, but in her virtue' [ShaoLan, p. 63].

Chastity is one of the main criterions in choosing a bride for both Chinese and Polish. That is, initially a man should care about his bride's and/or wife's virtue instead of her appearance. Similarly, description of prioritised chastity is found in Polish proverbs stating that it is beauty that complements chastity not the other way round: Uroda bez cnoty nie może $w$ stawe iść 'Beauty without chastity cannot get any fame' [NKPWPP, p. 598]; Uroda cnote krasi (zdobi) 'Beauty garnishes chastity' [NKPWPP, p. 598]; Człowiek bez cnoty, uroda bez serca, serce bez sity, za nic nie stoja 'A man without virtue, a beauty without a heart, a heart without strength, stand for nothing' [NKPWPP, p. 598].

It is noteworthy that in Chinese culture the emphasis on pre-marital abstinence and virginity also results in a continuous sex segregation, which is one of the characteristics of traditional Chinese gender culture rooted in the concept of chastity. Proverbially it is expressed in 冰清玉潔 (bìng qīng yù jié) 'As clean as ice and as pure as jade' meaning 'pure and noble, being a virgin' [ADCCE, p. 159].

By comparing a girl's chastity to jade, the proverb stresses its preciousness since in Chinese culture jade is a highly treasured gem. It represents goodness and physical attractiveness and is another symbol of beauty.

If a girl violated the rule and lost her virginity before marriage she was strongly condemned by the society and given offensive, pejorative names (e.g. 破鞋 (pò xié) 'broken shoe,' that is a 'loose woman') [8]. Likewise, Polish proverbially scorn unchaste females and despite their physical attractiveness describe them as immoral and those of little worth: Mało wazy uroda, gdy nie staje cnoty 'Beauty is worth very little if there is no virtue' [NKPWPP, p. 277]; Za diabla uroda, kiedy cnoty mato 'For the devil, beauty, when virtues are not enough' [NKPWPP, p. 271]; Uroda bez cnoty, wojsko bez hetmana, królewstwo bez rzadu nie moga w stawę iść 'Beauty without virtue, an army without a leader, a kingdom without a government cannot go in fame' [NKPWPP, p. 270]. 
Virtue - Aspirational. This group incorporates proverbs expressing female positive inner attributes that women in Chinese and Polish societies should aspire to and model their lives accordingly. Moreover, as it is clearly depicted in the enduring proverbial wisdom, Chinese set certain standards as guidance for a man and his family in choosing suitable brides. These criteria are known as 四德 (sì dé) or 'Four Virtues' that consist of 妇德 (fù dé) 'morality', 妇言 (fü yán) 'proper speech', 妇容 (fù róng) 'modest manner/ appearance', and 妇功 (fü gōng) 'diligent work.' It is a formed moral code of great value which is significant and widely recognised even nowadays:

婦德者 不必才名絕異 (fù té ché pù pì tsái míng chǘeh i)

婦容者 不必顏色美麗 (fü yúng ché pù pì yén sè měi li)

婦言者 不必利口辨詞 (fǜ yén ché pù pì lì kǒu pìen tzú)

婦工者 不必技巧過人 ( fü kūng ché pù pì chì chiăo kùo jén)

'A woman's virtues need not to be of the famous or uncommon kind; her face need not very beautiful; her conversation need not be very eloquent; and her work need not be very exquisite or surpassing' [Scar., p. 244].

Modesty and easy-going personality were highly prioritised among attributes young Chinese ladies should be equipped as in 窈宨淑女君子好述 (yăo tiăo shū nǘ, jūn ž̀ hào qiú) 'Modest, retiring young ladies are sorted by gentlemen' [Chen, p. 520]; 下氣小心䌆是婦女 (hsìa chì hsiăo hsìn tsái shìh fü nǘ) 'Good tempered and careful - she’s a good wife indeed' [Scar., 378].

In the patriarchal Chinese society, for centuries ignorance was considered a woman's virtue and was a positive attribute 女子無才便是德 (nü̈zǐ wú cái biàn shì dé) 'Ignorance is a woman's virtue' [ADCCE, p. 66].

Such positive public perception of ignorant females is explained by different societal expectations and family roles of husband and a wife. As confirmation to this, 'men outside, women inside' 男主外, 女内 (nán zhǔ wài nŭ rǔ nèi) is a relationship model generally widely accepted in China which resulted in gender stereotypes. The deep-seated belief persisted that the proper place for a woman was at home, where she was largely responsible for the upbringing and education of children and doing household chores: 侍奉箕帚 (shì fèng jī zhǒu) 'to perform wifely duties (cooking and cleaning)'. According to Yu and Xie [11] report, family labour division is based on gender stereotyping with the lion's share falling on the shoulders of the wife rather than a husband.

However, in Polish society intelligence and quick-wittedness are considered valuable and expected female characteristics while their absence is bitterly criticised - Urody dość, rozumu nie kaska 'Abundant beauty, poverty of intellect' [NKPWPP, p.74]; Rozum Bóg do urody nie przywiazal 'God did not attach brain to the beauty' [NKPWPP, p. 201]; Szkoda krasy, gdzie rozumu nie masz 'It's really a shame that beauty is not accompanied by brain' [NKPWPP, p. 195]

Additionally, warm-heartedness is sought in females as a desired positive attribute proverbially represented in Urody dość, a serdca mato 'Abundant beauty, little of heart' [NKPWPP, p. 74].

Obedience / Submission. In the Chinese culture, obedience is considered a positive attribute of a woman and the selected proverbs in this group elaborate the idea of model behaviour a Chinese woman has to follow: 嫁雞隨雞 嫁狗隨狗 (jià jī suí jī, jià gòu suí gǒu) 'Married to chicken follow chicken, married to dog follow dog' [Jiao, p. 148]; 夫以義為良。婦以順為正 (fū zhì yı̌ wéi liáng; fù yì shùn wéi chèng) 'In the husband fidelity is the thing that's good; in the wife obedience is the thing that's proper' [Scar., p. 372]; 夫唱婦隨 (fū chàng fù sui) 'Husband sings and wife follows / accompanies' [Scar., p. 373]; 在家由父。出嫁從夫 (tsài chiā yú fù; chū chià tsúng fūu) 'Unmarried, a woman obeys her father; married, her husband' [Scar., p. 242]; 夫妻無隔夜之仇 (fū năi fù chīn tīen; chī năi fü chin nǘ) 'Husbands are as Heaven to their wives; wives are the slaves of their husbands' [Scar., p. 377].

Historically, Chinese society has been strongly influenced by beliefs and values draw from Confucianism. It became the official government's state philosophy during the Han dynasty (206 BCE - 220 CE), and in particular during the time of Emperor Wu (141$87 \mathrm{BCE}$ ). Confucianism is based on the concept of relationship - 禮as an ethical system rather than a religion ( $l \grave{l})$. $L \grave{l}$ were rules and norms of social behaviour that dictate the manner in which Chinese people position themselves within a hierarchical society and perform their roles accordingly. As stated in the philosophical tradition of Confucianism there are 'five human relationships': sovereign and subject, father and son, elder and younger brother, friend and friend, and husband and wife. The last one is the first in origin and is of crucial importance, especially for a woman: 人倫有五夫婦為先; 大禮三千婚姻最重 (jén lün yǔ wǔ fū fù wéi hsīen; tà lǐsān chīen hün yīn tsùi chùng) 'There are Five Relations, but that of husband and wife stands first; there are three thousand great Rites, but that of marriage is most important' [Scar., p. 372].

According to Confucius teaching, in order to maintain a strict social order, women should be subordinate to men at every level of social and family hierarchy: 'It is the law of nature that woman should be held under the dominance of man.' Typically, the latter can be described as 'patriarchal, patrilineal and patrilocal,' that is officially dominated by men.

Being a good woman in the Chinese feudal society could be hard given the strict standards of being 'good'. One of the basic moral principles for women in a family life in Confucianism is called 三从 (sān cóng) and rendered as 'three obediences'. The concept of the three obligations states that 'The woman follows (and obeys) the man; in her youth, she follows her father and elder brother; when married, she follows her husband; when her husband is dead, she follows her son (在家從父母 出嫁從丈夫 夫亡從 子 (zài jiā cóng fù mù chū jià cóng zhàng fū fū wáng cóng zỉ)) [2]. Even the Chinese character 女 (nü 'woman') traditionally depicts an outline of a woman kneeling on the floor, showing her obedience to a man [10, p. 46]. The ideal relationship between husband and wife is based on the instant respect represented in the proverb 举案齐眉 (jǔ àn qi méi) 'holding the tray up to the eyebrows.' The proverb originated in the belief that in order to demonstrate appreciation for husband, a wife should serve him food with her head bowed and holding the tray up to her eyebrows. With such gender-based inequality, Chinese mirror the inferiority of women in their marriage life in the proverbial wisdom.

During their lifetime, Chinese women were always economically dependent on two families - the natal one and marital home although they never completely belonged to either of them. As a result, female submissive behaviour was cultivated in the Chinese families since childhood and girls were prepared for such long-adopted social norm of transferring to the husband's family. It is proverbially represented in在家由父。出嫁從夫 ( $t$ sài chia yú fù; chī chià tsúng fū ' Unmarried, a woman obeys her father; married, her husband' [Scar., p. 242].

We did not find any supportive evidence of the required submissive behaviour represented in Polish proverbs. So we assume that although female obedience and respect to her father (elder family members) at first and to her husband in future was expected, it did not reach the level of total subordination and selflessness. 
Conclusions. Through an ethnolinguistic approach a comparison of proverbs that express female inner positive attributes in the Chinese and Polish societies was carried out. It reveals social beliefs, ethnic and gender prejudice towards women, as well as accumulated ethno-cultural information.

The picture that emerges from the analysis of these traditional Chinese and Polish proverbs reveals virtuousness and chastity as similar inner positive attributes essential for females in both social settings. However, the Chinese alone give praise to humble and unintelligent females with easy disposition who should be seen but not heard whilst carrying out loyal duties towards her (male) master and his direct family (obedience/submission). Unlike Chinese, in the Polish society quick-wittedness and intelligence in a woman represent strongly desired female assets. Without these characteristics even a beautiful woman would lose her attractiveness and be scorned; besides, in this viewpoint, an attractive female would probably be less submissive and more stubborn too.

Further studies will widen the scope of this research aiming at identifying and comparing other inner and outer female attributes.

\section{References:}

1. Щедровицкий Г. П., Розин В. М. Концепция лингвистической относительности Б. Л. Уорфа и проблемы исследования «языкового мышления» // Семиотика и восточные языки. - 1967. - Москва. -222 с.

2. Adler J. A. Daughter/Wife/Mother or Sage/Immortal/Bodhisattva? Women in the Teaching of Chinese Religions // ASIANetwork Exchange. - Vol. XIV(2). - 2006. - Mode of access. - http://www2.kenyon.edu

3. Bartmińki J. Aspects of Cognitive Ethnolinguistics. / J. Zinken. - London/Oakville: Equinox, 2009. - 272 p.

4. Bartmiński J. Aspects of cognitive ethnolinguistics. / J. Zinken. London; Oakville, CT: Equinox, 2012. - 256 p.

5. Bhuvaneswar Ch. The Proverb and Its Definition: A Ka:rmik Linguistic Approach. / In C. Grandl, K. J. Mckenna (eds), Bis dat, qui cito dat. - Frankfurt am Main, 2015. - Mode of access. - http://www.academia.edu/25630080/Towards_a_Ka_rmik_Linguistic_Approach_ to the_Definition_of the Proverb_A_Series_of_Four_Articles

6. Gee J. P. An introduction to Discourse Analysis: Theory and Method: 话语分析入门: 理论与方法. Routledge, 2000. - 224 p.

7. Lee F., King J. Chinese Proverbs: How are Women and Men Represented? // GÉNEROS - Multidisciplinary Journal of Gender Studies. - 2015. - Vol. 4(1). - P. 559-585.

8. Mair V. Chinese terms of address for single ladies. - Mode of access. $-\mathrm{http}: / /$ languagelog.ldc.upenn.edu/nll/?p=4116

9. de Saussure F. A Course in General Linguistics. // In C. Bally, A. Sechehaye (eds). - (1916 [1959 translation]). - New York: McGrawHill.

10. Stacey J. Patriarchy and Socialist Revolution in China. Berkeley. Los Angeles/London, 1983. - 336 p.

11. Xie Y. Gender and Family in Contemporary China. University of Michigan. // Population Studies Center Research Report. - 2013. - Vol. 13(808).

\section{Bibliography}

(ADCCE) - A Dictionary of Cantonese Colloquialisms in English. - 2010. - Hong Kong. - 339 p.

(Chen) - Chen Y. Chinese Idioms and Their English Equivalents. - 1981. - Hong Kong. - 745 p. $328 \mathrm{p}$.

(Jiao) - Jiao L., Kubler C. C., Zhang W. 500 Common Chinese Idioms. An annotated Frequency Dictionary. - 2011. - Routledge. -

•(NKPWPP) - Nowa Księga Przysłów i Wyrażeń Przysłowiowych Polskich. Tom I-III. - 1969-1972. - Warszawa: Państwowy Instytut Wydawniczy.

- (Scar.) - Scarborough W. A Collection of Chinese Proverbs. - 1875. - Shanghai: American Presbyterian Mission Press. - 522 p.

-(ShaoLan) - ShaoLan H. Chineasy: The New Way to Read Chinese. (2014). - United Kingdom. - 192 p . 